\title{
KENDALA DAN UPAYA PENGEMBANGAN OBJEK WISATA BONO DI SUNGAI KAMPAR KECAMATAN TELUK MERANTI KABUPATEN PELALAWAN RIAU
}

\author{
Slamet Rianto ${ }^{1)}$ dan Santri $^{2)}$ \\ 1) Program Studi Pendidikan Geografi, STKIP PGRI Sumatera Barat \\ slametrianto.com@gmail.com \\ 2) Program Studi Pendidikan Geografi, STKIP PGRI Sumatera Barat \\ santri.@gmail.com
}

\begin{abstract}
Bono attractions Teluk Meranti in the Kampar river has long been known by the local community and society outside the area.. The potential development of one of the tourist destinations of special interest is very great because not only the arrival of world-class surfers are also attracted families join surfers to enjoy the beauty of Teluk Meranti village that has not been untouched by modernization. The study aimed to collect data and analyze data on: 1) The potential attraction owned by Bono. 2) Constraints faced in the development of attractions Bono. 3) The efforts made by the government and the community in the development of attractions Bono. This type of research is qualitative using interviews, observation and research directly spaciousness. The results of research in the field as follows: 1) The potential attraction that Bono Bono has become Icon in provincial and national. 2) Constraints faced in the development of attractions Bono among others: Street who has not been on the tarmac, villa or venue that is still inadequate, stalls where to eat the tourists are still lacking, there is no public transportation to transport tourists. 3) The efforts made by the government and the community in the development of attractions Bono is to prepare themselves in order to promote activities pariwisatai does not eliminate their cultural identity.
\end{abstract}

\section{Keywords: Constraints and Development Efforts Attractions Bono}

\section{Abstrak}

Objek wisata Bono di sungai Kampar Teluk Meranti ini sudah lama dikenal oleh masyarakat sekitar dan masyarakat ndi luar daerah tersebuta. Potensi pengembangan salah satu destinasi wisata minat khusus ini sangat besar karena tidak hanya kedatangan peselancar kelas dunia juga mengundang minat keluarga peselancar untuk ikut menikmati keindahan desa Teluk Meranti yang belum banyak tersentuh modernisasi. Penelitian bertujuan untuk mendapatkan data dan menganalisa data tentang : 1) Potensi yang dimiliki oleh objek wisata Bono. 2) Kendala yang dihadapi dalam pengembangan objek wisata Bono. 3) Upaya yang dilakukan oleh pemerintah dan masyarakat dalam pengembangan objek wisata Bono. Jenis penelitian adalah kualitatif dengan menggunakan metode wawancara, observasi dan penelitian lansung kelapangan. Hasil dari penelitian di lapangan sebagai berikut : 1) Potensi yang dimiliki objek wisata Bono yaitu Bono sudah menjadi Icon di Propinsi dan Nasional. 2) Kendala yang dihadapi dalam pengembangan objek wisata Bono antara lain: Jalan yg belum di aspal, Villa atau tempat penginapan yang masih kurang memadai, warung tempat makan para wisatawan masih kurang, angkot tidak ada untuk mengangkut para wisatawan. 3) Upaya yang dilakukan oleh pemerintah dan masyarakat dalam pengembangan objek wisata Bono yaitu mempersiapkan diri mereka dalam rangka memajukan kegiatan pariwisatai dengan tidak menghilangkan identitas budaya mereka.

\section{PENDAHULUAN}

Indonesia memiliki banyak potensi dan sumber daya alam yang belum dikembangkan secara maksimal, termasuk didalamnya di sektor pariwisata. Pembangunan bidang pariwisata diharapkan dapat memberikan manfaat bagi masyarakat, karena sektor pariwisata merupakan salah satu sektor pembangunan di bidang ekonomi. Kegiatan pariwisata merupakan salah satu sektor non migas yang 
diharapkan memberikan konstribusi yang cukup besar terhadap perekonomian negara.

Usaha mengembangkan dunia pariwisata indonesia ini didukung dengan UU nomor 10 tahun 2009 tentang kepariwisataan yang menyebutkan keberadaan objek wisata pada suatu daerah akan sangat menguntungkan, antara lain meningkatkan Pendapatan Asli Daerah (PAD), meningkatkan taraf hidup masyarakat, dan memperluas kesempatan kerja mengingat semakin banyaknya pengangguran saat ini, meningkatkan rasa cinta lingkungan serta melestarikan alam dan budaya setempat. Oleh karena itu pengembangan dan pelaksanaan kepariwisataan harus diupayakan secara terencana. Bertahap dan berkesinambungan setelah melalui pengkajian secara cermat.

Kepariwisataan merupakan bagian yang erat dengan upaya pembangunan ekonomi nasional, dalam tahap pembangunan nasional saat ini pariwisata telah memberikan sumbangan yang besar terhadap negara sebagaimana tercantum dalam GBHN 1993 yang berbunyi : pembangunan pariwisata diarahkan pada peningkatan pariwisata menjadi sektor andalan yang mampu menggalakkan ekonomi, termasuk kegiatan sektor lain yang terkait sehingga lapangan pekerjaan, pendapatan masyarakat, pendapatan daerah dan pendapatan negara meningkat melalui upaya pengembangan dan pendayagunaan berbagai potensi kepariwisataan.

Melalui pembangunan kepariwisataan diharapkan dapat mendorong pembangunan daerah, memperkenalkan alam, nilai, dan budaya bangsa yang beranekaragam serta memupuk rasa cinta tanah air dalam memperkokoh persatuan bangsa. Kepariwisataan berarti melibatkan berbagai pihak mulai dari pemerintahan, investor, pengusaha maupun masyarakat setempat.

Hakikatnya implikasi dari kegiatan pariwisata yang sangat menentukan bagi perkembangan pariwisata itu adalah : seseorang melakukan perjalanan, adanya prasarana lalu lintas, sarana transportasi dan komunikasi, adanya sarana akomodasi, adanya daya tarik daerah tujuan wisata, adanya faktor kemudahan serta tersedianya unsur-unsur pelayanan yang memadai. Akan tetapi yang sangat menonjol permasalahan tersebut adalah masalah promosi yang masih kurang, partisipasi industri pariwisata yang masih lemah, media publikasi terutama dalam negeri sangat langka serta lemahnya koordinasi lintas sektoral. 
Di Kabupaten Pelalawan banyak terdapat beberapa tempat pariwisata, lebih tertariknya di daerah teluk meranti. Teluk Meranti adalah sebuah Kecamatan di Kabupaten Pelalawan, Riau, Indonesia. Keadaan alamnya yaitu berupa dataran rendah berawa-rawa dengan lahan gambut yang cukup luas. Wilayah Teluk Meranti dibelah oleh aliran sungai kampar yang bermuara ke selat Malaka. Sepanjang aliran sungai tersebut membentang hutan lebat tropis yang sangat luas dikedua sisi sungai tersebut. Penduduk asli Teluk Meranti adalah suku melayu. Potensi besar yang ada di kecamatan Teluk Meranti yaitu dibidang pariwisata, yaitu objek wisata fenomena alamnya berupa ombak Bono yang terdapat disungai kampar.

Dahulu `gelombang Bono ditakuti oleh masyarakat Desa Teluk Meranti. Namun, seiring perkembangan wisata selancar Sungai Kampar, masyarakat menyadari pentingnya peranan gelombang Bono dalam menggerakan perekonomian mereka.

Objek wisata Bono di sungai kampar Teluk Meranti ini sudah lama dikenal masyarakat sekitarnya. Potensi pengembangan salah satu destinasi wisata minat khusus ini sangat besar karena tidak hanya kedatangan peselancar kelas dunia juga mengundang minat keluarga peselancar untuk ikut menikmati keindahan Desa Teluk Meranti yang belum banyak tersentuh modernisasi.

Keunikan pariwisata Bono ini terjadi di daerah aliran sungai. Bono merupakan fenomena alam unik yang terjadi di Sungai Kampar Kabupaten Pelalawan Provinsi Riau. Bono adalah fenomena alam yang datang sebelum pasang. Air laut mengalir masuk dan bertemu dengan air sungai Kampar sehingga terjadi gelombang dengan kecepatan yang cukup tinggi, dan menghasilkan suara seperti suara guntur dan suara angin kencang.

Walaupun pemerintah sudah melakukan berbagai usaha dan terobosan baru dengan melahirkan berbagai ide dan kebijaksanaan seperti membangun jalan untuk menuju ke objek wisata dan membangun sarana dan prasarana, namun ternyata dalam dunia kepariwisataan indonesia sebagaimana kondisi yang lainnya yang terdapat di negara-negara berkembang pada umumnya tidak terlepas dari berbagai permasalahan dan kendala yang perlu dibenahi secara serius. Seperti yang terdapat pada objek wisata Bono di Teluk Meranti ini banyak sekali unsur penghambat atau kendala yang ditemui dalam usaha pengembangannya sehingga fasilitas yang 
dibutuhkan dalam usaha pengembangannya juga tidak ditemui pada objek wisata tersebut.

Fasilitas itu berupa, jalan belum memadai, kecil dan belum di aspal untuk transportasi menuju ketempat pariwisata Bono tersebut. Selain itu, sarana transportasi berupa angkot untuk membawa wisatawan kesana tidak ada dan hanya bisa menggunakan transportasi pribadi kemudian villa atau tempat penginapan bagi wisatawan asing masih kurang, serta masih kurangnya warung-warung tempat makan bagi wisatawan. Hal lain yang tidak ada kursi-kursi untuk tempat santai.

Berdasarkan observasi di lapangan, Kecamatan Teluk Meranti mempunyai potensi di bidang pariwisata, potensi Bono ini memiliki gelombang yang merupakan endapan seperti lumpur dan pasir dasar sungai kuala kampar yang menggulung besar yang berada di daerah aliran sungai kampar dan sangat diminati oleh para peselancar kelas dunia untuk memecahkan rekor dunia dalam hal berselancar dengan jarak terjauh dan dalam waktu terlama.

Keunikan dari fenomena gelombang Bono ini sudah merupakan nilai positif tersendiri, potensi tersebut perlu dibenahi dan dikembangkan untuk menarik perhatian para wisatawan baik Nasional maupun Internasional.

\section{METODOLOGI}

Menurut Erdaningsih (2007) bahwa sumber utama dalam penelitian kualitatif adalah kata-kata dan tindakan. Sumber data tertulis, foto dan statistik merupakan data utama. Melihat jenis data yang di atas sumber yang diperoleh dari kata-kata dn tindakan yang dimaksud berasal dari informan kunci, sedangkan sumber tertulis diperoleh dari buku, arsip, dokumen dan hasil penelitian yang relevan dengan masalah penelitian. Sumber foto dan gambar merupakan sebagi pendukung dalam mendeskripsikan data yang diperoleh dari lapangan. Sumber data statistik yang telah tersedia digunakan sebagai sumber data tambahan bagi penelitian kualitatif.

Agar data dapat dikumpulkan dengan baik, maka teknik pengumpulan data yang digunakan dalam penelitian ini adalah :

\section{Observasi}

Teknik yang dilakukan untuk melihat daya tarik objek wisata dalam hal pengembangannya.

2. Wawancara 
Wawancara kepada informan bertujuan untuk mengetahui kekuatan, kelemahan, peluang dan ancaman tentang objek wisata Bono di sungai Kampar (Gunawan 2009). Dalam teknik ini melakukan :

a. Wawancara bebas

Wawancara bebas berlansung secara alami, tidak mengikat atau diatur oleh sesuatu pedoman, atau oleh suatu informat yang baku. Nmun demikian keterangan-keterangan yang diberikan diarahkan pada data yang diinginkan.

b. Wawancara terstruktur bertujuan

memperoleh keterangan khusus yang berkaitan dengan masalah penelitian yang disusun dalam bentuk instrument penelitian berupa daftar wawancara dan pedoman observasi.

3. Pemotretan

Pemotretan yang dilakukan bertujuan untuk memperkuat dan mendukung data yang diperoleh. Hasil pemotretan disajikan sesuai dengan data dan persoalan penelitian. (Gunawan : 2009)

Menurut Sugiyono dalam Novita (2012) dalam penelitian kualitatif tidak di lakukan uji hipotesis melainkan hanya mendeskripsikan informasi dan apa adanya sesuai dengan variabel yang di teliti teknik analisis data yang digunakan dalam penelitian ini adalah :

a. Reduksi Data

Reduksi data bertujuan untuk memilih hal-hal pokok yang sesuai dengan fokos penelitian data-data reduksi memberikan gambaran lebih tujuan tentang hasil pengamatan dan mempermudah penelitian untuk mencari satu waktu.

b. Display Data

Display data adalah melakukan pengontrolan terhadap data yang diperoleh dilapangan dan selanjutnya disajikan dalam bentuk tabel

c. Pengambilan Keputusan danVerifikasi Data awal penelitian berusaha mencari pola, model, tema, hubungan, permasa lahan dan sebagainya. Untuk lebih akurat data penelitian harus melakuka n pengamatan ulang dan melihat data baru.

1. Keabsahan Data 
Teknik menguji tingkat keabsahan data yang diperoleh dilakukan dengan beberapa cara antara lain :

a. Perpanjangan Keikutsertaan

Dalam penelitian ini, peneliti berfungsi sebagai instrument artinya keikutsertaan peneliti pada objek yang diteliti sangat menentukan sekali dalam pengumpulan data. Hal ini bertujuan supaya data yang diperoleh betul-betul dapat dipercaya karena sudah berulang kali diamati.

b. Ketekunan Pengamatan

Ketekunan pengamatan bertujuan menentukan ciri-ciri dan unsurunsur dalam situasi sangat relevan dengan persoalan atau isu yang dicari, dalam hal ini peneliti akan mengamati potensi Pariwisata Bono di Sungai Kampar Kecamatan Teluk Meranti Kabupaten Pelalawan Riau.

c. Tringulasi

Teknik tringulasi adalah untuk memeriksa keabsahan data yang memanfaatkan sesuatu diluar data itu untuk memeriksa keabsahan pengecekan atau sebagai perbandingan terhadap data yang diperoleh. (Moleong dalam Afriyenti :2011).

Tringulasi sumber, metode penyelidikan dan teori untuk sumber dan teori tringulasi sumber artinya peneliti mengecek kembali tingkat keberadan suatu informasi berdasarkan waktu dan alat, baik pada saat yang sama maupun saat yang berbeda, sedangkan dalam tringulasi teori penulis melihat peristiwa dalam perspektif teori, pandangan dan pendapat orang lain dalam bentuk tertulis.

2. Penarikan kesimpulan

Dari awal penelitian berusaha untuk mencari pola, model, tema, hubungan, persamaan dan sebagainya. Dari data tersebut peneliti berusaha mencari kesimpulan. Untuk lebih akuratnya data, peneliti harus melakukan verifikasi data dengan cara melakukan pengamatan ulang dan melihat data baru.

\section{PEMBAHASAN}

Kecamatan Teluk Meranti merupakan salah satu Desa yang terletak di Kabupaten Pelalawan bagian Timur daerah paling Barat Propinsi Pekanbaru Riau berdasarkan letak astronomis Kecamatan Teluk Meranti dengan posisi koordinat : 041'30" LU - $0^{\circ} 03^{\prime} 30^{\prime \prime} \mathrm{LS}$ dan $103^{\circ} 12^{\prime} 54^{\prime \prime} \mathrm{BT}-102^{\circ} 12^{\prime} 54^{\prime \prime} \mathrm{BB}$. 
Letak Geografis Kecamatan Teluk Meranti sebagi berikut :

- Sebelah Utara : Kec. Kuala Kampar

- Sebelah Selatan : Kec. Kerumutan

- Sebelah Barat : Desa Kuala Panduk

- Sebelah Timur : Kec. Pelalawan

Kecamatan Teluk meranti terdiri dari 9 Desa yaitu desa kuala panduk, petodaan, teluk meranti, pulau muda, pangkalan terap, teluk binjai, gambut mutiara, labuhan bilik dan segamai. Secara geografis seluruh desa di Kecamatan Teluk Meranti bertofografi daerah aliran sungai dan pantai dengan luas 4. 239,44 km.

Berdasarkan data dari Lurah Kecamatan Teluk Meranti tahun 2014 jumlah penduduk Kecamatan Teluk Meranti berjumlah (3236) jiwa yang terdiri dari lakilaki sebanyak (1708) jiwa dan perempuan (1528)

Berdasarkan hasil wawancara penulis dengan informan diatas maka dapat disimpulkan bahwa Objek Wisata Bono di Sungai Kampar Kecamatan Teluk Meranti Kabupaten Pelalawan Riau sebagai berikut :

Pertama, dilihat dari potensi Bono ini sudah menjadi Icon pariwisata tidak hanya di Kabupaten Saja tetapi di Propinsi Riau bahkan sudah menjadi Icon Nasional. Berbagai macam kegiatan yang di adakan pada objek wisata Bono ini seperti Pagelaran seni budaya seperti ; lomba pacu sampan pada ombak Bono (Bakudo Bono), lomba foto grafer tentang Ivant Bono dan masih banyak lagi, dari setip Kabupaten memamerkan kebudayaan daerah masing-masing.

Bono ini adalah gelombang air sungai yang terdapat di sungai Kampar dan hanya ada satu-satunya di Indonesia. Banyak wisatawan dari luar Negara yang datang untuk melihat dan merasakan berselancar pada ombak Bono ini.

Menurut Yoety (1983) potensi terdiri dari potensi Alam yaitu : a) Potensi wisata yang benar-benar belum dibentuk pleh kreatifitas tangan manusia, b) Potensi Budaya yaitu potensi wisata yang mengandung unsur-unsur budaya, c) Alam Budaya dan Alam Artifisial yaitu potensi wisata alam yang telah dimodifikasi oleh kreatifitas tentang manusia agar dapat lebih menarik lagi.

Kedua, dalam pengembangan objek wisata Bono ini tidak terlepas dari berbagai kendala, dilihat dari kondisi sarana dan prasarananya yang masih kurang ini dapat dilihat dari kondisi jalannya yang belum di aspal, padahal jalan sangat menentukan perkembangan suatu daerah sementara angkot untuk 
mengangkut wisatawan belum dan ada hanya menggunakan transportasi pribadi, selain itu Villa atau tempat penginapan masih kurang, warung-warung tempat makan para pengunjung atau wisatawan masih sedikit.

Pembangunan infrastruktur sangat menunjang pengembangan wisata gelombang Bono. Bagi masyarakat luar daerah yang tidak terbiasa dengan perjalanan jauh dengan keadaan jalannya yg belum di aspal, Villa tempat penginapan yan masih kurang dan lain sebagainya, mereka menimbang untuk berangkat ke daerah objek wisata Bono tersebut karena banyak kendala yang mereka hadapi, sementara mereka melakukan perjalanan untuk mencarai kesenangan dan kenyamanan.

Menurut Kreck dalam yoeti (1983 : 184-191) sarana yaitu perusahaanperusahaan yang memberikan pelayanan wisatawan, baik secara lansung maupun tidak lansung dan hidup serta kehidupannya banyak tergantung pada kedatangan wisatawan.

Ketiga, upaya pemerintah baik dari Pemerintah pusat maupun daerah saling bekerja sama dalam menggalakkan Bono ke masyarakat luar daerah khususnya masyarakat umum. Selain itu pemerintah mempersiapkan masyarakat agar tidak canggung dalam menghadapi wisatawan agar menjadi tuan rumah yang memiliki sikap ramah tamah,sikap terbuka menerima wisatawan asing dengan memegang teguh identitas daerah atau kebudayaan daerah.

Pemerintah setempat sudah membuat balai untuk wisatan melihat Bono dengan jarak dekat sehingga bagi wisatawan yang tidak bisa berselancar mereka bisa menyaksikan menyaksikan ombak Bono dengan jaelas. Dan Pemerintah pusat dan daerah bekerjasama membangun sarana dan prasarana ariwisata Bono yang masih kurang dan bertahap demi kenyamanan dan keamanan para wisatawan.

Menurut muljadi (2009) peranan pemerintah terhadap pengembangan objek wisata yaitu : a) Memberikan sumbangan terhadap penerima devisa yang sangat diperlukan untuk membiayai pembangunan nasional, meringankan beban hutang Negara dan memelihara nilai mata uang rupiah terhadap mata uang asing, b) Menciptakan lapangan kerja tidak hanya terbatas di kota tetapi justru menyebar kepedesaan, c) Peningkatan pendapatan pemerintah pusat dan daerah melalui berbagai pajak dan retribusi, d) Peningkatan pendapatan masyarakat, e) 
Pemerataan, pembangunan dan mengurangi ketimpangan pembangunan baik secara structural, spasial dan sektoral.

Keempat, masyarakat di Kecamatan Teluk Merantin sejauh ini mendukung kegiatan pariwisata Bono ini, secara materil memang tidak ada karena bantuan secara materil itu hanya ada dari pemerintah pusat dan daerah, sementara masyarakat hanya mendukung dan memberikan sumbangan tenaga dan pikiran.

Dukungan dari masyarakat setempat mereka mengadakan gotong royong membersihkan desa agar suasana tetap nyaman dan pengunjungpun ikut merasakannya, selain itu bagi ibu-ibu mereka membuat makanan khas daerah teluk meranti yang dibuat dari labu manis menjadi kue bolu kecil-kecil untuk dicicipi oleh wisatawan.

Bakaruddin (2009) peranan masyarakat dalam pengembangan objek wisata antara laian : a) Masyarakat sadar wisata, agar mengetahui lebih jauh apa yang dikerjakan dan masalah-masalah yang dihadapi bertujan untuk pembangunan pariwisata, b) Produk wisata dipandang sebagai aspek melekat pada masyarakat, sehingga keberhasilan pembangunan pariwisatasuatu proses rekayasa sosial, c) Dalam hal meningkatkan cerita produk wisata terutama tenaga-tenaga, d) Masyarakat sebagainsumber informan tentang hal yang sebenarnya tradisi-tradisi di daerah tempat wisata.emas.

\section{Sapta Pesona}

1. Aman. Kemanan yang dimaksud suatu kondisi yang memberikan suasana tentram bagi wisatawan, bebas dari rasa takut dan tidak khawatir akan keselamatan jiwa raga dan harta milik, bebas dari ancaman, gangguan dan tindakan kekerasan. Dari segi keamanan objek wisata Bono di sungai Kampar ini masih tergolong aman-aman saja.

2. Tertib, kondisi yang tertib merupakan suatu yang didambakan oleh setiap orang termasuk wisatawan. Dari segi ketertiban masih sangat kurang ini tampak dari segi keadaan lalu lintas yang kurang lancar karena keadaan jalanya yang belum di aspal sementara pengunjung yang datang banyak, masih Nampak orang yang berdesak-desakan disaat menyaksikan objek wisata Bono.

3. Bersih, merupakan suatu keadaan atau kondisi lingkungan yang menam 
pilkan suasana bebas dari kotoran, sampah, limbah, penyakit dan pencemaran. Dari segi kebersihan yang terdapat pada objek wisata Bono ini masih tergolong bersih, baik dari segi lingkungannya, penggunaan dan peralatan perlengkapan dan dari segi pakaiannya.

4. Sejuk, lingkungan yang serba hijau, segar, rapi memberikan suasana atau keadaan sejuk, nyaman dan tentram. Dari segi kesejukan masih dirasakan karena di daerah Kecamatan Teluk Meranti ini masih dikelilingi hutan hal ini tampak disekitar sungai Kampar masih dikelilingi hutan.

5. Indah, suasana yang menampilkan lingkungan yang menarik dan sedap dipandang baik dari segi warna, tata letak, tata ruang bentuk ataupun gaya dan gerak yang serasi dan selaras, sehingga member kesan yang enak dan cantik untuk dilihat. Dari segi keindahan selama ini masih terjaga keindahan alamnya.

6. Ramah Tamah, merupakan suatu sikap dan perilaku seseorang yang menunjukkan keakraban, sopan, suka membantu, suka tersenyum, dan dan menari hati. Dalam menyambut kedatangan wisatawan masyarakat setempat selalu menghormati tamunya dan dapat menjadi tuan rumah yang baik memiliki sikap yng terbuka dengan tidah merubah identitas kebudayaan setempat.

7. Kenangan, adalah kesan yang melekat dengan kuat pada ingatan dan perasaan seseorang yang disebabkan oleh pengalaman yang diperolehnya. Kenangan yang terdapat ada yang berupa yang indah dan menyenangkan seperti keindahan ombak Bono yang menakjubkan, atraksi budaya daerah yang khas dan mempesona, cendera mata yang menunjukkan khas daerah dan ada juga kenangan yang tidak menyenangkan seperti akomodasi yang masih kurang.

\section{KESIMPULAN}

Berdasarkan hasil penelitian dan pembahasan sebagaimana yang dikemukakan pada bab sebelumnya, maka dapat disampaikan :

1. Potensi yang dimiliki oleh objek wisata Bono di sungai Kampar yaitu Bono sudah menjadi Icon pariwisata bagi masyarakat tidak hanya di Kecamatan Teluk meranti tetapi sudah menjadi Icon se Propinsi Riau dan juga sudah menjadi Icon Nasional. 
2. Kendala-kendala yang dihadapi dalam pengembangan objek wisata Bono itu seperti yang dilihat dari yang pertama keadan jalan yang belum memadai jalannya kecil dan belum di aspal, daerah tersebut juga belum ada angkot untuk membawa wisatawan kesana. Hanya menggunakan transportasi pribadi. Villa atau tempat penginapan bagi wisatawan masih kurang. Dan masih kurangnya warung-warung tempat makan bagi wisatawan.

3. Upaya pemerintah dalam pengembangan objek wista ini adalah mempersiapkan masyarakat setempat untuk ikut memajukan dan mendukung kegiatan ini dengan tidak menghilangkan identitas mereka.

4. Upaya masyarakat untuk mengembangkan objek wisata Bono ini yaitu ikut berpartisipasi dan sama-sama bergotong royong untuk mendukung kegiatan ini.

\section{DAFTAR PUSTAKA}

Afriyenti 2011. Pengembangan Objek Wisata Bendungan PT. Brantas di Kenagarian Bonjol Kecamatan Kota Besar Kab. Dharmasraya. Skripsi

Bakaruddin. 2009. Perkembangan dan permasalahan kepariwisata.Padang: UNP Press.

Erdaningsih 2007. Studi Tentang Upaya Pengembangan Objek Wisata Alam Bukit Taratak (Puncak) di Kecamatan Sutera Kabupaten Pesisir Selatan. Skripsi Maleong, J. Lexy. 1988. Metode Kualitatif. Jakarta : Proyek Pengembangan Lembaga Pendidikan Tenaga Kerja.

Moleong, J. Lexy. 2010. Metode Penelitian Kualitatif. Bandung : PT. Remaja Rosdakarya

Sugiyono. 2011. Metode Penelitian Pendidikan. Bandung. Alfabeta

Yoety ,Oka A. 1986. Pengantar Ilmu Pariwisata. Jakarta : angkasa 